\title{
Agency pleads for less support
}

\section{Washington}

US FEDERAL agencies are not well known for complaining that they have been voted too much money. That, however, seems to be the attitude of the Environmental Protection Agency (EPA) to a recent vote in the House of Representatives to accelerate and expand the agency's "superfund" programme for clearing up toxic waste dumps. EPA says it would not be able to spend the House's proposed budget increase fast enough.

Superfund came into existence in 1980 to deal with chemical emergencies and, more controversially, the chronic problem of deteriorating waste dumps. There are at least 18,000 potentially hazardous sites known to EPA, and more than 500 have already been placed on a "national priority" list of sites posing a long-term threat to health or environment. The priority list could soon increase to more than 2,000 sites.

EPA's budget for the first five years of the superfund programme was $\$ 1,600$ million, but the House of Representatives voted overwhelmingly earlier this month to increase this more than sixfold, to a total of $\$ 10,200$ million for the next five years. But there were conditions. This apparent generosity was tied to a strict timetable for action: congressional critics of EPA maintain that the agency got off to a poor start on superfund and are fond of pointing out that only six clean-ups have been completed in the 4 years since the programme began. General support for EPA has decreased markedly, while many of its scientists, demoralized, have moved to jobs in academic institutions or industry.

The House of Representatives has now said it wants EPA to start on-site remedial action at 150 locations each year, as well as speeding up its study effort. Mr Lee M. Thomas, EPA's deputy administrator for solid waste and emergency response, has described these requirements as "unrealistic" in congressional testimony. Thomas estimated that the mandatory schedules alone would cost EPA $\$ 7,400$ million over the 5 years, with other provisions in the House bill increasing the cost still further. The result, according to Thomas, could be "the paradox of actually slowing down clean-up operations".

This stark prediction, perhaps unsurprisingly, cuts no ice with Representative James Florio (Democrat, New Jersey), who sponsored the House superfund reauthorization bill. Congressional analysts who support the House initiative say that EPA has deliberately exaggerated the cost of clean-ups to make a political point.

One controversial clause in the House bill that would have given the automatic right to sue in federal courts to those claiming to have been injured by toxic chemicals was defeated by a narrow majority, much to the relief of the chemical industry. At present, claims against polluters have to go through the state courts first, where the standards of proof required may be more difficult for claimants to meet. Many state laws also impose time limits on claims which may make court action difficult if the alleged damage occurred many years before.

One revision to superfund that the house failed to take on board was a proposal, favoured by the chemical industry, to broaden the scope of its financing. Under the existing legislation, superfund is paid for largely by manufacturers and importers of 42 critical "feedstock" chemicals. This formula means that a high proportion of the cost falls to relatively few companies, while other historical polluters - such as mining companies - get away scot-free. (Superfund is used only in an emergency and when a culprit cannot be found; the cost of clean-up operations rests with the polluter otherwise). The house did, however, retain the option of introducing a "waste end" tax - to be paid on waste produced. This form of taxation would, it is hoped, encourage more recycling and spread the cost of the programme in the way the chemical industry wants.

The Senate has not yet voted on its superfund reauthorization. Although some say it will follow the House lead during September, there is strong pressure on senators to wait until after the presidential election in November. The job is certainly not urgent, because the existing authorization will carry the programme through until the end of 1985 . The administration fears that an overgenerous authorization will cause political damage, and is anxious to keep the issue out of sight for as long as possible.

\section{Albanian universities}

\section{Old problems found anew}

Postgraduate training at the Albanian university of Tirana is to be considerably expanded next term, with 50 courses as against 27 now, according to the Albanian press agency ATA. This appears to be a direct response to swingeing criticisms of Albania's higher education system by Ramiz Alia, chairman of the presidium of the People's Assembly, when he visited the university on 31 May. Since the purges of 1982, Alia has emerged as front runner in the succession to the ageing party leader Enver Hoxha, for whom he now increasingly deputizes. His speech at Tirana, the full text of which reached the West only at the beginning of August, took the form of a commentary on Hoxha's message to the university for its silver jubilee in 1982.

Higher education in Albania (Tirana University and a handful of agricultural, veterinary, pedagogic, physical culture and fine arts colleges) is, according to party doctrine, strongly geared to the needs of the economy; young people completing their studies are drafted to "serve the cause of the country and socialism wherever needed"'. Yet, according to Alia, higher education is frequently little more than a mechanical repetition by lecturers of textbook facts, while practical work and the training of students in technical dexterity is frequently neglected. Jobrelated training of undergraduates is "acute", and too little is being done to "discover and encourage new talent" and to develop students" "practical and creative spirit" and "technical intuition".

According to Alia, one of the main causes of this shortfall is the "mediocrity" and even "incompetence" of lecturers. During the past few years, he said, the party has been pressing for the replacement of these unsatisfactory persons but found it difficult to identify them due to a "spirit of concession and compromise" still widespread in academic circles. Just how this cover-up has operated is not entirely clear since, according to Alia, the incompetents can be recognized by their poor standard of training, the long delays in their own progress up the academic ladder and the paucity of their publications. A simplc check of curricula vitae and a scan of Albania's 30 or so learned journals would surely serve to locate the most flagrant offenders.

Tardiness in obtaining higher qualifications is, in Alia's opinion, the distinguishing mark of slackers who do not recognize that research is for higher education the "healthy and essential breath needed for progress"'. Some slackers, he complained, only defend one or two postgraduate theses, and then remain at that level. (Albania has a fivestage hierarchy of academic degrees and titles.)

At the same time, some of the ablest young graduates are immediately overburdened with teaching duties instead of bcing able to concentrate on their own postgraduate studies. The university and colleges, Alia urged, should make more "rational" use of such "cadres", since what the country most requires of them is " a high rapid and intensive qualification to the standard of contemporary science, ... an integrated, scientific and professional training, ... a a solid mastering of basic foreign languages, a gradual but regular involvement in research activity both within and outside the higher schools and publication ... from textbooks to genuine scientific monographs".

Vera Rich 